\author{
IGNAZIO FLORIS ${ }^{1}$ - ARTURO COCCO ${ }^{1 *}$ - FRANCO BUFFA ${ }^{1}$ \\ ROBERTO MANNU ${ }^{1,2}$ - ALBERTO SATTA ${ }^{1}$
}

\title{
INSECT PESTS OF EUCALYPTUS PLANTATIONS IN SARDINIA (ITALY) $\left({ }^{1}\right)$
}

\author{
(1) Dipartimento di Agraria, Sezione di Patologia Vegetale ed Entomologia, Università degli Studi di Sassari, Viale Italia \\ 39, 07100, Sassari \\ ${ }^{(2)}$ Istituto per lo Studio degli Ecosistemi, Consiglio Nazionale delle Ricerche, Traversa la Crucca 3, 07100, Sassari \\ *Corresponding author: acocco@uniss.it
}

Floris I., Cocco A., Buffa F., Mannu R., Satta A. - Insect pest of Eucalyptus plantations in Sardinia (Italy)

In Sardinia (Italy), Eucalyptus plantations cover approximately 23,000 hectares, above all in the southern part of the island. There is a complex of phytophagous insect pests that is threatening the health status of Eucalyptus trees. The most recent invasions include the sap-suckers, Glycaspis brimblecombei, Blastopsylla occidentalis, and the bronze bug, Thaumastocoris peregrinus. Other pest species have also been reported, including the gall wasps, Ophelimus maskelli and Leptocybe invasa, the longhorn beetles, Phoracantha semipunctata and P. recurva, and the weevils, Gonipterus scutellatus and Polydrusus (= Metallites) parallelus. Defoliation caused by the gypsy moth, Lymantria dispar, have also been frequently observed in various Eucalyptus-planted areas of Sardinia.

KeY WoRDS: Eucalyptus, pests, Sardinia, monitoring, biological control.

\section{INTRODUCTION}

In Italy, the first introduction of a Eucalyptus (E. robusta) species dates to 1803 in the English garden of the royal palace at Caserta (Campania). A few years later, several other species were introduced and cultivated in the Botanical Gardens in Naples and in the Hortus Camaldulensis. The latter was an acclimatization garden created by the Count of Camaldoli, to whom Dehnhardt dedicated the species E. camaldulensis in 1832 (BRUNDU, 2017). In the early decades of the 19th century, Eucalyptus was only of ornamental interest and, according to some estimates, 78 different species were introduced for this purpose (BRUNDU, 2017). In 1869, the trappist monks of the Abbey of the Three Fountains in Rome started a Eucalyptus cultivation, believing that it had antimalarial properties due to both the presence of essential oils and its ability to reclaim wetlands. The seeds were brought from Australia by Monsignor Good, Bishop of Melbourne, who attended the First Vatican Council in Rome in December 1869.

At the beginning of the 20th century, extensive forestry programs were started, including wide plantations in land reclamation areas, along railway lines in Sicily, and for the production of the timber poles used in mines in Sardinia. Between 1930 and 1940, eucalypt species were widely used as windbreaks in the Agro Pontino area (Lazio region, central Italy) and in Sardinia (BRUNDU, 2017).

In the 1950s, extensive reforestation projects were carried out in Sicily and Sardinia, often without taking into account the ecological requirements of the species introduced. In the same period, Italy contributed to the knowledge of Eucalyptus species and played a prominent role in their

\footnotetext{
${ }^{1}$ Original scientific contribution presented and discussed at the National Symposium on "Health status of Eucalyptus plantations in Italy", Oristano (Centro Congressi Hotel Anfora, Tramatza) - Italy, March 24-25, 2017.
}

diffusion; for example, in October 1956 in Rome the $1^{\text {st }}$ World Congress on Eucalyptus was organized. The large number of species and the wide adaptability to different environments make it difficult to generalize the ecological characteristics and potential uses of the Eucalyptus species (BRUNDU, 2017).

Today, in addition to serving as windbreaks and as melliferous and polliniferous species, Eucalyptus species are also used to produce paper pulp, firewood, coal, and poles (DEIDDA et al., 2016; BRUNDU, 2017).

In recent years, there has been a renewed interest in these species all over the world. For example, in 2015 Brazil authorized the use of transgenic Eucalyptus plants in reforestation. In Europe, Eucalyptus species are defined as exotic species by the European Regulation (EU) No. $1143 / 2014$. Thus, both the introduction of new species and new plantations have to be carried out in compliance with legislation and good sustainable agricultural and forestry management practices. In Sardinia, Eucalyptus plantations are estimated to cover about 23,000 ha, excluding windbreaks and plantings smaller than one hectare, and are mainly located $(90 \%)$ below $400 \mathrm{~m}$ a.s.l. in the southern part of the island (DEIDDA et al., 2016).

The most widely cultivated species in the Mediterranean basin is the river red gum, Eucalyptus camaldulensis Dehnh., followed by E. globulus Labill. and E. gomphocephala DC.

Over the last few decades, a number of phytophagous insects and pathogenic fungi have threatened Eucalyptus species in the Mediterranean area. Among the most recent exotic invasive species, the red gum lerp psyllid, eucalyptus psyllid, and bronze bug have caused extensive damage to eucalypt plantations in consecutive years. In addition, gall wasps and some beetles, such as eucalyptus longhorned borers and weevils have also been reported. In some areas, the gypsy moth, Lymantria dispar (L.), has also caused defoliation.

This paper presents a comprehensive review of the 
Eucalyptus insect pests and their impacts on eucalypt plantations in a Mediterranean context (Sardinia, Italy).

\section{THE MAIN PHYTOPHAGOUS INSECTS}

\section{PSYLLIDS}

The invasive red gum lerp psyllid, Glycaspis brimblecombei Moore (Hemiptera: Psyllidae), is the most serious Eucalyptus pest in the Mediterranean area (Fig. I, 1) (MENDEL et al., 2016), especially for E. camaldulensis, which has been shown to be extremely susceptible to $G$. brimblecombei infestations (DEIDDA et al., 2016). The red gum lerp psyllid was recorded for the first time in Italy in 2010 (LAUDONIA and GARONNA, 2010) and spread rapidly in central and southern regions, including the islands. It was reported for the first time in Sardinia in spring 2010 (BUFFA, 2015).

Eggs are laid on the leaf surface, where nymphs develop under protective white conical coverings (lerps) composed of lipids, proteins and carbohydrates (Fig. I, 2) (MoRGAN, 1984). Adults and nymphs are phloem feeders and produce large amounts of honeydew, thus promoting the development of sooty mold (MENDEL et al., 2016; CUELLO et al., 2018). The damage resulting from leaf feeding includes foliar discoloration, and, in cases of heavy infestations, dieback, early leaf fall and reduced plant growth (BRENNAN et al., 1999, 2001; DAANE et al., 2005, 2012). Defoliation in consecutive years can lead to the death of young plants or susceptible clones (DAANE et al., 2005).

In March 2012, a monitoring program was started in Sardinia in 12 sites located in the main areas of Eucalyptus cultivation (BuFFA, 2015; DEIDDA et al., 2016; MANNU et al., 2018). Adults and preimaginal stages were monitored by yellow sticky traps and leaf samples, respectively, in order to estimate the pest population density and natural mortality. Adult captures increased steeply from May-June and reached the highest values in late June-mid July, depending on the year, decreasing significantly from September onwards (MANNU et al., 2018). Egg and nymph dynamics showed a similar pattern (Fig. II).

The specific koinobiont parasitoid Psyllaephagus bliteus Riek (Hymenoptera: Encyrtidae) (Fig. I, 3) has been effectively used in classical biological control programs in Mediterranean-climate areas (DAANE et al., 2005, 2012; DAhlsten et al., 2005; FerReIRA Filho et al., 2015). The parasitoid oviposits preferentially on third- and fourth-instar nymphs and develops inside late fourth and fifth instars (DAANE et al., 2005; 2012). In 2015, the rate of $P$. bliteus parasitism was similar throughout the island, although an earlier peak was observed in July both in southern and central Sardinia (Fig. III).

The eucalyptus psyllid, Blastopsylla occidentalis Taylor (Hemiptera: Psyllidae) (Fig. I, 6), is native to Australia and was first reported in Italy in 2006 (LAUDONIA, 2006). However, B. occidentalis has established itself in other countries outside its native area, including New Zealand (TAYlor, 1985), California (TAYlor, 1985), Mexico (HODKINSON, 1991), Brazil (BURCKHARDT et al., 1999; SANTANA and BURCKHARDT, 2007), Chile (BURCKHARDT and Elgueta, 2000), Argentina (Bouvet et al., 2005), South Africa (Anonymous, 2007), Cameroon (Dzokou et al., 2009), Turkey (AYTAR et al., 2011), Spain and Portugal (PÉrez Otero et al., 2011), and Uruguay (MARTíNeZ et al., 2014).

The adult females, which are generally darker than males and measure approximately $1.5 \mathrm{~mm}$ in length, can lay the eggs on shoots, leaves, flowers and twigs. As with other sap-sucking insects, the eggs are laid preferentially during the main periods of the flushing rhythm of trees (Soufo and TAMESSE, 2015). The oviposition activity of B. occidentalis is closely related to the water conditions of host plants, as the psyllid population density decreased significantly at lower humidity levels in Cameroon (SOUFO and TAMESSE, 2015). Unlike red gum lerp psyllid juveniles, preimaginal stages of $B$. occidentalis are not characterized by lerps but produce a protective white waxy secretion, on which sooty mould can grow (TAYLOR, 1985; MENDEL et al., 2016). The eucalyptus psyllid completes 5-6 generations under tropical conditions (SOUFO and TAMESSE, 2015).

In the regions where Eucalyptus trees are used as windbreaks and for fuelwood production, exploitation as a source of pollen and nectar for honeybees is also common. In such Eucalyptus plantations, B. occidentalis is considered one of the main concerns of eucalypt health (MENDEL et al., 2016). In fact, field observations carried out in the Mediterranean area have shown that the psyllid infested mainly young sprouts (Fig. I, 7) and inflorescences (Fig. I, 8 ) in formations of $E$. camaldulensis trees, causing a premature fall of flowers in the following spring period (BUFFA, 2015). Losses caused by B. occidentalis attacks can be exacerbated by the simultaneous presence of the red gum lerp psyllid infestations. Concomitant infestations of both psyllids could easily endanger the survival of the delicate floral structures of the Eucalyptus, with a subsequent impact on the production of the unifloral honey. In fact, joint attacks of the two psyllids led to a $85 \%$ decrease in eucalyptus honey production in Sardinia in the two years following G. brimblecombei introduction (BUFFA, 2015). Although a different pattern was not found along a latitudinal gradient, the mean abundance of $B$. occidentalis adults in Sardinia was lower in the southern part of the island, reaching a peak of approximately 20 adults per trap in late July (Fig. IV).

Other psyllid species belonging to Ctenarytaina have been introduced in the last few years in Europe: $C$. eucaliptii (Maskell), C. spatulata Taylor and C. peregrina Hodkinson.

\section{THE BRONZE BUG}

The bronze bug, Thaumastocoris peregrinus Carpintero \& Dellapé (Hemiptera: Thaumastocoridae) (Fig. I, 4) is a sap-sucking pest infesting eucalyptus plantations. It originates from Australia (NOACK and ROSE, 2007; NADEL et al., 2010), where it has been reported as a harmful species since 2002. The bronze bug is now widespread in many other areas: Africa (2003) (Zimbabwe, South Africa) (JACOBS and NeSER, 2005; GILIOMEE, 2011), South America (2005) (Uruguay, Paraguay, Brazil, Chile, Argentina) (CArpintero and Dellapé, 2006; Noack and Coviella, 2006; MARTíNEZ and BIANCHI, 2010; WILCKEN et al., 2010; IDE et al., 2011; SOLIMAN et al., 2012), Europe (2011), and recently the Middle East (2014) and New Zealand (Sopow et al., 2012). The first report in Europe was recorded in Italy (2011) in the Lazio region (LAUdonia and SASSO, 2012), followed by Portugal in 2012 (GARCIA et al., 2013), Sicily in 2014 (Suma et al., 2014) and Sardinia in 2015 (DEIANA et al., 2018), where the first record was reported in the south of the island on E. camaldulensis.

The bronze bug is known to attack at least 30 Eucalyptus species and three common commercial hybrids (JACOBS and NeSER, 2005; CARPINTERo and Dellapé, 2006; NoACK and Coviella, 2006). E. urophylla and E. grandis were found to be the most suitable host species, as nymph development 

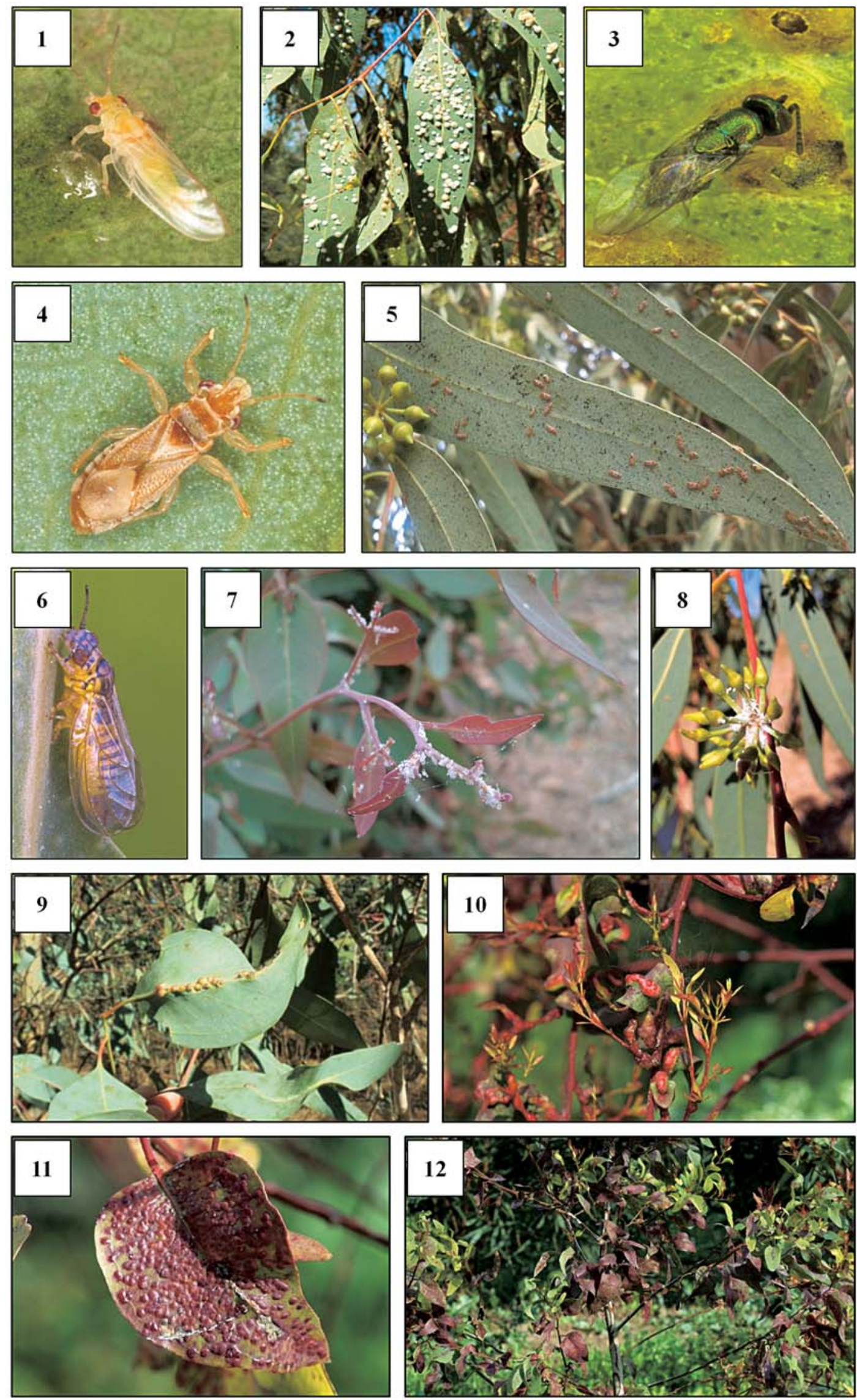

Fig. I - 1) adult male of Glycaspis brimblecombei; 2) leaves covered by lerps; 3) adult of Psyllaephagus bliteus; 4) adult of Thaumastocoris peregrinus; 5) grouping of T. peregrinus adults feeding on Eucalyptus leaves; 6) adult of Blastopsylla occidentalis; 7) B. occidentalis infestation on a young shoot; 8) B. occidentalis infestation on Eucalyptus flowers; 9) Leptocybe invasa galls on Eucalyptus leaves; 10) damage caused by L. invasa infestation; 11) Ophelimus maskelli galls on upper side of Eucalyptus leaf; 12) Eucalyptus young plant damaged by $O$. maskelli infestation. 


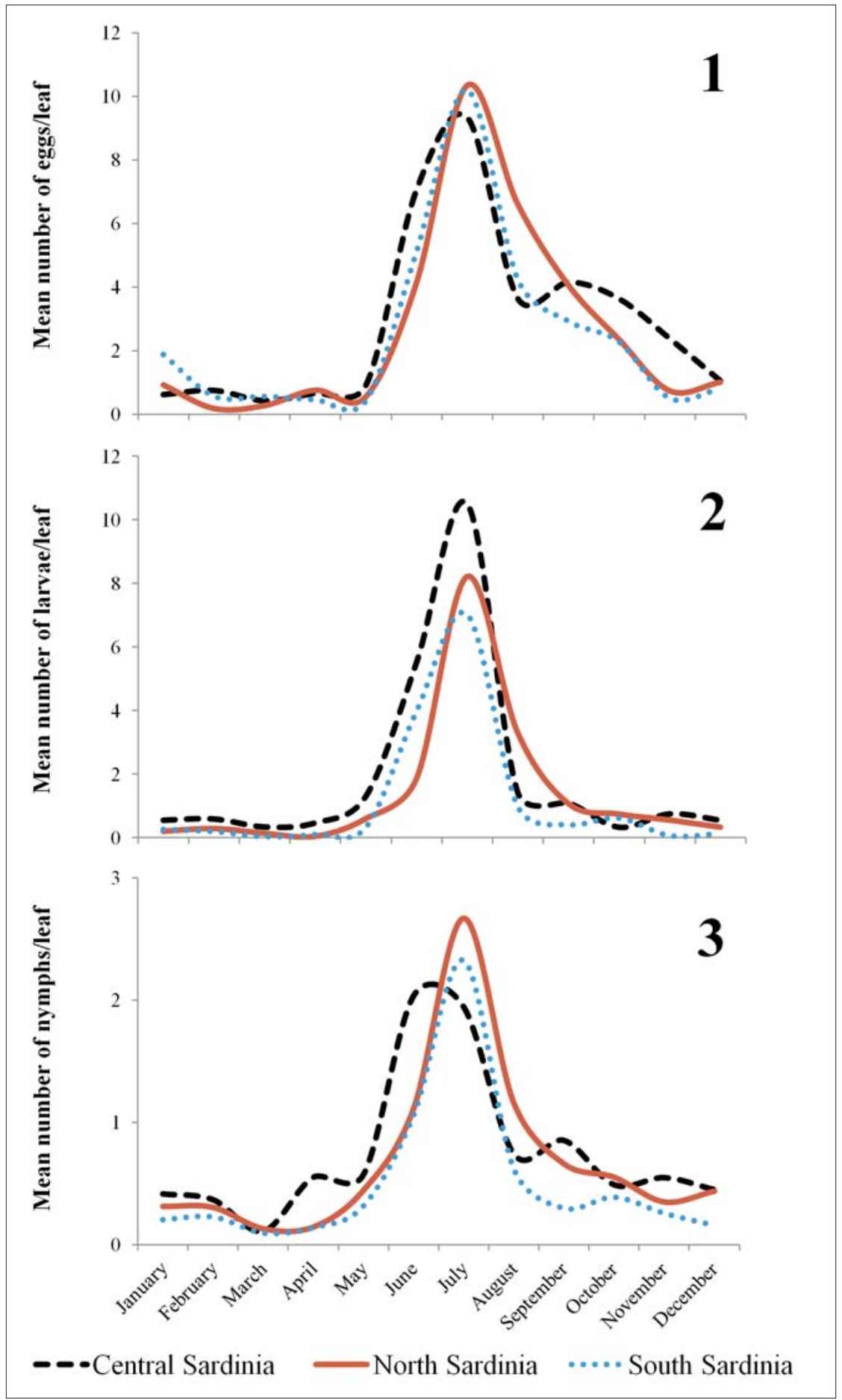

Fig. II - Mean number of Glycaspis brimblecombei: (1) eggs, (2) larvae, and (3) nymphs per leaf observed during 2015 in North, Central and South Sardinia.

was faster and female fecundity higher than on $E$. camaldulensis (Soliman et al., 2012). Adults are light brown in color with darker spots, approximately $3 \mathrm{~mm}$ long, with a flattened body. Eggs are black, elliptical in shape and can be found individually or in patches on leaves and twigs. Nymphs develop through five instars to the adult stage in approximately 20 days, whereas adult longevity ranges from 14 to 42 days (NOACK and Rose, 2007; SOlman et al., 2012). The bronze bug completes multiple generations per year and all life stages can be observed at the same time on leaves.

The damage is caused by the feeding punctures of adults and preimaginal stages on expanded leaves (Fig. I, 5), causing silvering chlorosis that evolves to leaf bronzing and drying. The canopy turns progressively to a brownishreddish discoloration, and thus has the common name of "winter bronzing" (Fig. I, 5). In addition to this symptom, early leaf fall and complete defoliation have been observed. Repeated infestations may cause branch dieback, reduce tree growth, and lead to the death of young weak plants (Soliman et al., 2012).

In Sardinia, field surveys were carried out in $E$. camaldulensis plantations in order to study the seasonal occurrence of the pest in two consecutive years (2015: 12 monitoring sites; 2016: three sites). Adults were monitored by yellow sticky traps, whereas egg and nymph density was 
Fig. III - Mean rate of Psyllaephagus bliteus parasitism on Glycaspis brimblecombei nymphs in 2015 in North, Central and South Sardinia.

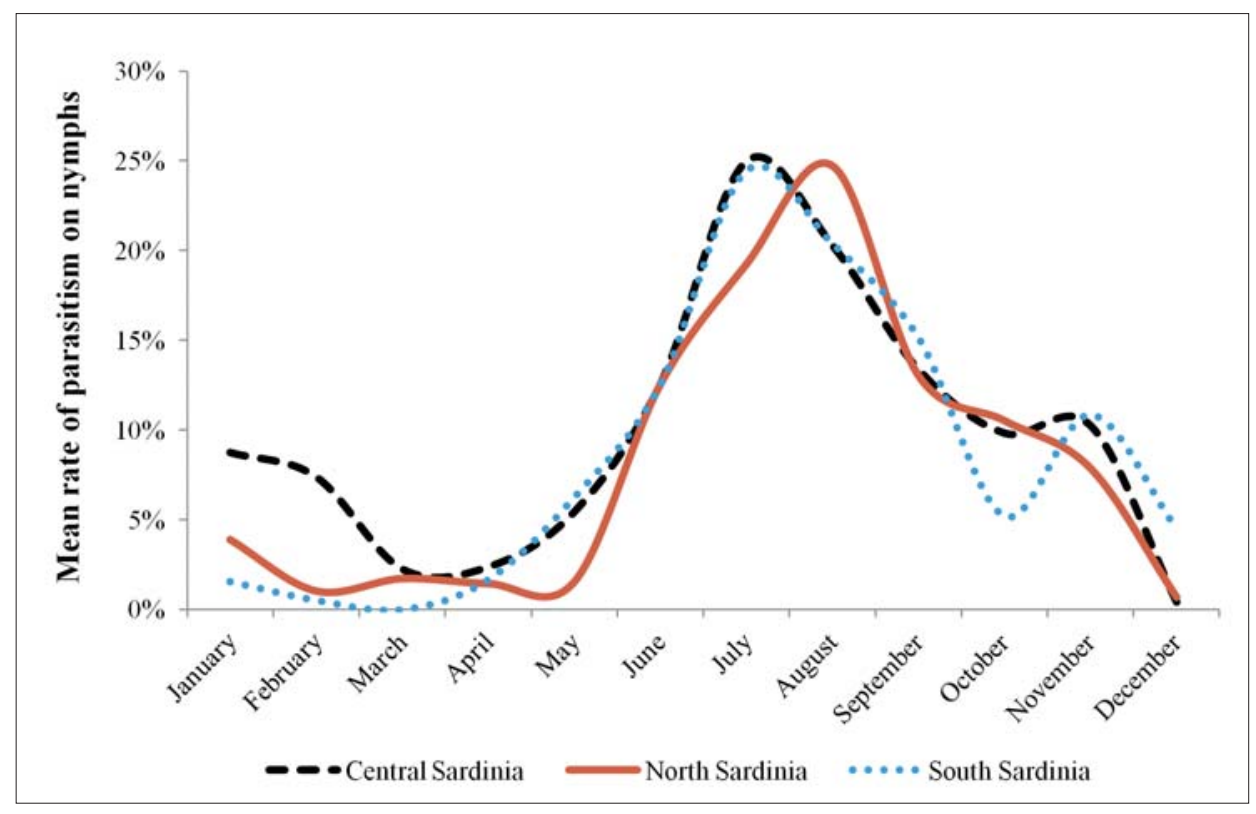

Fig. IV - Mean number of Blastopsylla occidentalis adults per trap captured in 2015 in North, Central and South Sardinia.

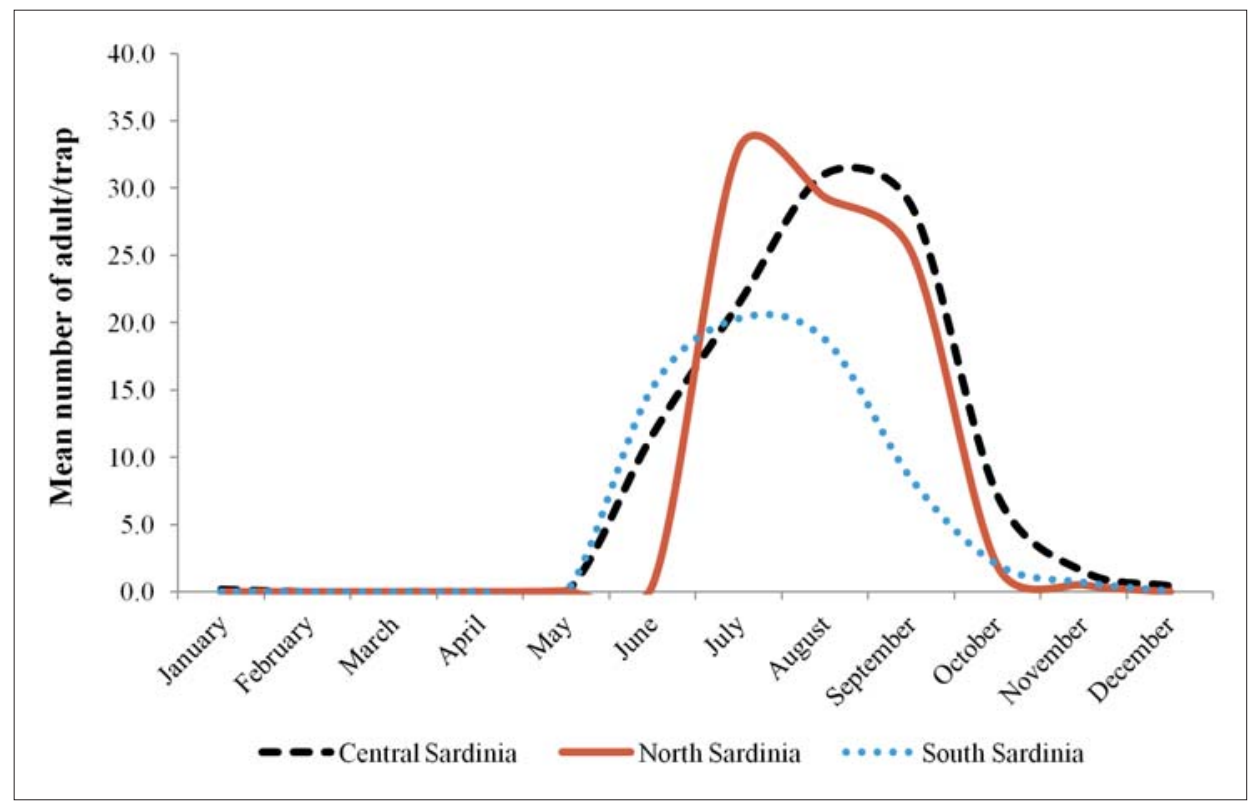

determined by sampling twigs (JimÉNEZ-Quiroz et al., 2016). The population dynamics in 2015 and 2016 showed high levels of adults in September, with a similar pattern for eggs and nymphs (DEIANA et al., 2018). In addition, both the adults and the juvenile stages were also observed in the winter, suggesting that $T$. peregrinus can also be considered as being well established on the island (DEIANA et al., 2018).

The most promising control strategies are currently based on biological control, in particular using the wasp, Cleruchoides noackae Lin \& Hube (Hymenoptera: Mymaridae), an egg parasitoid that was recently confirmed as a potential biological control agent of $T$. peregrinus (BARBOSA et al., 2017).

\section{GALL WASPS}

The gall wasps Leptocybe invasa Fisher \& La Salle and Ophelimus maskelli (Ashmead) (Hymenoptera: Eulophidae) have been recently considered as serious pests of Eucalyptus trees (BRANCO et al., 2016). L. invasa, commonly known as blue-gum chalcid wasp, is native to Australia (Mendel et al., 2004), and its infestations can cause significant damage and production loss (MENDEL et al., 2004; PETRO et al., 2015; AHMED et al., 2017).

As a rule, $L$. invasa reproduces by thelytoky (MENDEL et al., 2004), although male adults have been found in Turkey (DOgANLAR, 2005) and India (AKhtAR et al., 2012). Females lay eggs in the midrib and petiole of newlydeveloped leaves and in young stems and shoots, inducing a decrease in shoots and leaf growth of Eucalyptus (Fig. I, 9 and 10). The damage caused by the blue-chalcid gall wasp is probably due to changes in the leaf hydraulic architecture, as a reduction of both the development of stomata and a minor vein density have been observed in L. invasa-infested trees (ToNG et al., 2016). This insect has been reported as a serious pest of various Eucalyptus species worldwide (DitTriCH-SCHRÖDER et al., 2012; PETro et al., 2015), as E. camaldulensis are one of the most suitable hosts for its development (BRANCO et al., 2016).

O. maskelli also originates from Australia and was 
accidentally introduced into the Mediterranean region in 1999, where it was initially misidentified as $O$. eucalypti (Arzone and Alma, 2000; Viggiani and Nicotina, 2001). After its first report in Italy as $O$. eucalypti, the wasp has been observed in other Mediterranean areas on $E$. camaldulensis trees, including Spain (PUJADE-VILlAR and RiBA-Flinch, 2004), Greece (KAVALliERATOS et al., 2006), France (EPPO, 2006), Portugal (BRANCO et al., 2006), and Tunisia (DHAHRI et al., 2010). O. maskelli has also been reported in southern Asia (LAwson et al., 2012), South Africa (HuRLEY, 2014), and California (BurKs et al., 2015). Contrary to $L$. invasa, the galls induced by $O$. maskelli occur exclusively on the leaf blade of Eucalyptus leaves, forming typical round button-shaped galls (Fig. I, 11) (Protasov et al., 2007). Under particular environmental conditions, the surface of the infested leaves can be entirely covered with galls (Fig. I, 12) (BRANCO et al., 2016).

The populations of both gall wasps, as well as the presence of the specific parasitoid of $O$. maskelli, Closterocerus chamaeleon (Girault) (Hymenoptera: Eulophidae), were monitored from 2013 to 2014 in a Mediterranean area (BUFFA, 2015), showing a within-year pattern with two peaks of abundance for both $L$. invasa and $O$. maskelli. The highest number of galls per leaf occurred in the early spring and late summer for $O$. maskelli and $L$. invasa, respectively (BUFFA, 2015).

\section{WEEVILS}

The leaf-feeding beetle Gonipterus scutellatus Gyllenhal (Coleoptera: Curculionidae) (Fig. V, 1) is native to Australia and is probably the most studied weevil species infesting Eucalyptus trees worldwide. G. scutellatus species, which is also known as Eucalyptus weevil or Eucalyptus snout-beetle, belongs to a complex of cryptic species, whose revision is still in progress (NEWETE et al., 2011; MAPONDERA et al., 2012). Different species of the G. scutellatus complex have been accidentally introduced in Africa, America, Europe and New Zealand (Newete et al., 2011; MAPONDERA et al., 2012). G. scutellatus was first reported on Eucalyptus trees in Italy in 1975 (ARZONE, 1976).

G. scutellatus can cause severe damage to Eucalyptus trees mainly outside its native range, in which a rich community of predators and parasitoids has been shown to be able to control weevil infestations (ToOKE, 1953; LOCH and Floyd, 2001; LOCH, 2008; LOCH and MATSUKI, 2010). In newly introduced areas, a different susceptibility of Eucalyptus species to G. scutellatus infestations and development has been observed (CORDERO RIVERA and Santolamazza Carbone, 2000; Newete et al., 2011). E. viminalis is considered the most susceptible species to the snout beetle (TOOKE, 1953), although a variability in the weevil host preference has been reported in different countries (Clarke et al., 1998; HANKS et al., 2000; LOCH 2006).

Adult females are polygynous and can lay more than 300 eggs during their lifetime (EPPO, 2005). The eggs are laid on leaves in capsules containing approximately 8-10 eggs. The weevil can complete up to four generations per year, even though only two generations have been recorded in Italy (EPPO, 2005). Larvae of G. scutellatus attack leaves and twigs (Fig. V, 2), whereas adults feed exclusively on leaf edges leading to a generalized dieback of shoot tips and the development of tufts of epicormic shoots (EPPO, 2005). Successive defoliations negatively affect the tree growth and a stag-headed appearance occurs in the presence of severe infestation. Occasionally, infested-trees may split and die.

The use of natural enemies and tolerant Eucalyptus species is the most sustainable alternative to control $G$. scutellatus infestations, whereas chemical treatments have a potential negative effect on various Eucalyptus pollinators (EpPo, 2005). The egg parasitoid Anaphes (Patasson) nitens (Girault) (Hymenoptera: Mymaridae) has been used in controlling snout beetle populations in Italy (ARZONE, 1985). Based on preliminary observations, no detectable damage caused by G. scutellatus has been observed in Sardinia.

Polydrusus (Metallites) parallelus Chevrolat (Coleoptera: Curculionidae) (Fig. V, 3) is an endemic species of Sardinia, Corsica and Elba which feeds on Eucalyptus trees in its distribution range. However, the biology of this insect is unknown. Adults are common in spring and summer, and larvae presumably live underground feeding on plant roots. Damage caused by the feeding activity of $P$. parallelus was detected in Sardinia in April and May 2013 on Eucalyptus shoots (Fig. V, 4). The presence of $P$. parallelus was also recorded in the spring of 2014 throughout the island (BUFFA 2015). Damage to Eucalyptus, which has never been reported before, appeared to be significant in young plants. Adults feeding on Eucalyptus caused annular erosions on young branches, thus determining the break and subsequent drying of the attacked branches (Fig. V, 5).

\section{LONGHORN BEETLES}

The two-closely related species of longhorn beetles, Phoracantha semipunctata (Fabricius) and $P$. recurva Newman (Coleoptera: Cerambycidae), are above all associated with Eucalyptus. P. semipunctata (Fig. V, 6) was first detected in Sardinia in the 1970s, representing the first detection of the pest in Europe (TASSI, 1969; PIRAS et al., 1970). A few years after its detection, the species had spread throughout the surrounding area in which Eucalyptus trees were growing, particularly in southern Italy (ROMANO, 2007; LONGO, 2009). P. semipunctata adult females live one or more months and can produce up to 300 eggs, which are laid in groups of 3-30 under the loose bark of Eucalyptus trees.

The eggs hatch 7-14 days after oviposition, depending on the temperature. First-instar larvae can either chew a hole directly in the inner bark or mine the outer bark before making its way to the bark-cambium-xylem interface. Larval development lasts on average 90 days (MENDEL, 1985). Mature larvae excavate pupal chambers in the wood, sealing the chamber entrance with wood shavings and frass. After the pupation period, which lasts approximately 40 days in Mediterranean field conditions (MENDEL, 1985), adult beetles emerge from the same entry holes by chewing through the plugs of frass. The adult beetle can complete its life cycle in 3-4 or 9 months when eggs are laid during early spring or late summer, respectively (MENDEL, 1985). Hence, there are generally 2-3 generations per year.

The longhorn beetle $P$. recurva (Fig. V, 7) was discovered in Sardinia in 2006 (CILlo et al., 2006), although it has been in Italy since 1992 (PALMERI and CAMPOLO, 2006). The life cycle of the insect differs somewhat from that of the other longhorn beetles that infest Eucalyptus trees, as $P$. recurva adults can emerge earlier than $P$. semipunctata (RomAno, 2007). Today, $P$. recurva in Sardinia has almost completely displaced the congeneric species, which was very common until 2004, resulting in a greater number of Eucalyptus plantations infested exclusively by $P$. recurva (ROMANO, 2007).

The two longhorn beetle species can cause serious damage to young trees (Fig. V, 8), and are considered a potential threat to Eucalyptus reforestation (MENDEL, 1985; RomANO, 2007). The presence of both P. semipunctata and 

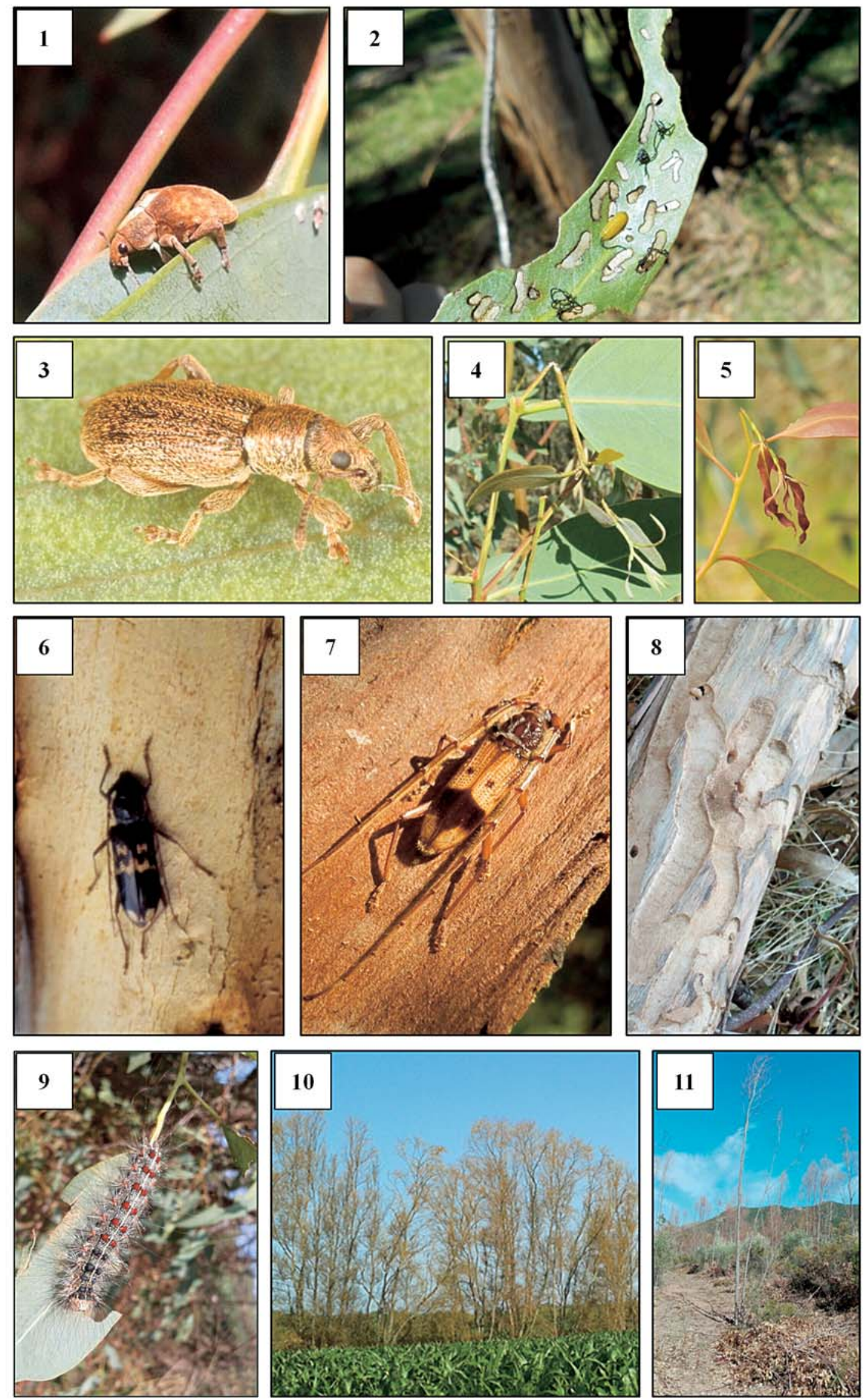

Fig. V - 1) adult of Gonipterus scutellatus; 2) leaf damaged by feeding activity of G. scutellatus larvae; 3 ) adult of Polydrusus parallelus; 4) and 5) young shoots damaged by P. parallelus infestations; 6) adult of Phorachanta semipunctata; 7) adult of $P$. recurva; 8) galleries of Phorachanta species on Eucalyptus tree; 9) mature larva of Lymantria dispar; 10) windbreak of Eucalyptus trees defoliated by L. dispar; 11) complete defoliation of Eucalyptus young trees caused by L. dispar. 
$P$. recurva coupled with other pests threatens the sanitary status of Eucalyptus trees and makes the control of longhorn borers necessary, especially by enhancing the physiological status of Eucalyptus trees or using resistant Eucalyptus species (PAINE and Millar, 2003).

\section{GYPSY MOTH}

The gypsy moth, Lymantria dispar (L.) (Lepidoptera: Erebidae), is a univoltine pest species which is considered one of the main risks to oak woods worldwide (LUCIANO and Prota, 1985; MCFAdDEN and MCMANUS, 1991). The adult female gypsy moth is creamy white and flightless, whereas the adult male can fly several kilometers. Egg masses, which are laid on the trunks of trees during the summer, are covered by the abdominal hairs of the female which will protect the eggs until the following spring. Hence, larvae (Fig. V, 9) start feeding on young leaves after hatching, and pass through either five (male) or six (female) instars before the prepupal stage. Gypsy moth populations are characterized by cyclical fluctuations of their population density, which are commonly known as gradations (CAMPBELL, 1981). During the first period of gradation (i.e. latency phase), the population density is at a harmless level for several years. After this period, the population density increases gradually in 2-3 years (i.e. progradation), reaches a peak or outbreak (i.e. culmination), which can last for two consecutive years, and naturally decreases (i.e. retrogradation) until returning to a latency period. The complete defoliation of over 60,000 hectares of cork oak forests has been recorded in Sardinia during a gypsy moth outbreak (LUCIANO and PROTA, 1985).

Defoliation causes a significant reduction in photosynthetic activity and can negatively affect the tree growth, as well as compromise the health of forest stands when there are other abiotic (e.g. drought) or biotic stresses (e.g. fungal diseases). Moreover, defoliation during the summer tends to discourage tourism in infested areas, resulting in an additional economic loss.

Although in the Mediterranean area the gypsy moth is mainly associated with the Quercus tree species (CocCO et al., 2010; MANNU et al., 2017), it is a very polyphagous pest, capable of feeding on more than 300 host plants including some Eucalyptus species (LEONARD, 1981; MCFAdDEN and MCMANUS, 1991; LieBHOLd et al., 1995). L. dispar larvae feeding on leaves of different Eucalyptus species under laboratory conditions have shown a high variability in development and survival, indicating both the variability and limited ability to process some secondary metabolites (MATSUKI et al., 2011). However, the complete defoliation of Eucalyptus trees has recently been observed in Sardinia (Fig. V, 10, 11). These occasional infestations are more likely to be due to $L$. dispar populations spreading either actively or passively from close outbreak foci.

\section{CONCLUSION}

Sardinia is one of the most important areas of the Mediterranean basin for the cultivation of Eucalyptus tree species. In the last few years, several insect pests infesting Eucalyptus trees have been reported, including the leaffeeding insects $G$. brimblecombei, B. occidentalis and $T$. peregrinus. These insects increase the complexity of Eucalyptus pest fauna already present throughout the entire area, such as gall wasps, longhorn beetles, and weevils. In addition, the defoliations caused by $L$. dispar and the symptoms of decay caused by the fungus Neofusicoccum australe have been recently found in some limited areas (DEIDDA et al., 2016). The health status of Eucalyptus trees in Sardinia has severely deteriorated.

A monitoring program carried out from 2012 to 2016 as part of the project "Programma triennale di controllo biologico della Psylla lerp dell'eucalipto Glycaspis brimblecombei e monitoraggio delle problematiche fitosanitarie dell'eucalipto in Sardegna" financially supported by the "Regione Autonoma Sardegna - Assessorato Difesa Ambiente, Tavolo Tecnico Difesa Fitosanitaria Piante Forestali", investigated the health status of Eucalyptus in Sardinia (FLORIS and LUCIANO, 2017). The program also evaluated the economic impact of the most important pests on the quality and quantity of unifloral Eucalyptus honey, which represents more than $50 \%$ of the entire honey production in Sardinia (FLORIS et al., 2016).

As a consequence of the increasing interest in Eucalyptus species as forestry and melliferous resources, a specific plan providing information on the most effective and sustainable management strategies for Eucalyptus plantations is needed. In line with international standards (IPPC/FAO, EPPO), a "collection field" of the Eucalyptus genus could be set up in order to: (1) evaluate the adaptation of different species, subspecies and hybrids to Mediterranean environmental conditions; (2) detect the presence of new pests and pathogens and assess the different susceptibilities of Eucalyptus species and hybrids; (3) evaluate the biological and ecological characteristics of different species, subspecies and hybrids of Eucalyptus in order to support their potential use as pollen resources for honey production; (4) increase ecological knowledge of plant-rhizosphere interactions focused on the naturalization of species and hybrids and their potential role as "biological invaders".

\section{ACKNOWLEDGMENTS}

The authors gratefully acknowledge the "Regione Autonoma della Sardegna, Tavolo Tecnico Difesa Fitosanitaria Piante Forestali, Assessorato Difesa Ambiente Servizio Tutela del suolo e politiche forestali" for the financial support of the research project "Programma triennale di controllo biologico della Psilla lerp dell'eucalipto Glycaspis brimblecombei e monitoraggio delle problematiche fitosanitarie dell'eucalipto in Sardegna".

\section{REFERENCES}

Ahmed M.Z., Hernandez Y.V., Skelley P., Rohrig E., Mckenzie C., Osborne L.S., Mannion C., 2017 Eucalyptus gall wasp, Leptocybe invasa Fisher \& La Salle (Insecta: Hymenoptera: Eulophidae), an emerging pest of eucalyptus in Florida. - Florida Department of Agriculture and Consumer Services, Division of Plant Industry, Issue No. 436, Accessed December 2017.

AKhtar M., PATANKar N., GAUR A., 2012 - Observations on the biology and male of eucalyptus gall wasp Leptocybe invasa Fisher \& La Salle (Hymenoptera: Eulophidae). - Indian J. Entomol., 74: 173-175.

ANONYMOUS, 2007 - Blastopsylla occidentalis: another new Eucalyptus pest in South Africa. - Plant Protection News, 72: 2-3.

Arzone A., 1976 - Un nemico dell'Eucalipto nuovo per l'Italia. - Apicoltura moderna, 67: 173-177.

ARZONE A., 1985 - Biological control of the eucalyptus snout beetle in Italy. - Bulletin SROP 8(1): 70-73. 
Arzone A., Alma A., 2000 - Eulofide galligeno dell'Eucalipto in Italia. - Inf. Fitopatol., 50: 43-46.

AYTAR F., DAĞDAŞ S., DURAN C., 2011 - Australian insects affecting eucalyptus species in Turkey. - Silva Lusit., 19: 41-47.

Barbosa L.R., Peruffo Rodrigues A., Da Silva Soler L., Vique Fernandes B., Monteiro De Castro e Castro B., WilCKen C.F., ZANUNCIO J., 2017 - Establishment in the Field of Cleruchoides noackae (Hymenoptera: Mymaridae), an Exotic Egg Parasitoid of Thaumastocoris peregrinus (Hemiptera: Thaumastocoridae). - Florida Entomologist, 100(2): 372-374.

Bouvet J.P.R., Harrand L., Buckhardt D., 2005 Primera cita de Blastopsylla occidentalis y Glycaspis brimblecombei (Hemiptera: Psyllidae) para la República Argentina. - Revista de la Sociedad Entomológica Argentina, 64: 99-102.

Branco M., Battisti A., Mendel Z., 2016 - Foliage Feeding Invasive Insects: Defoliators and Gall Makers. In: Insects and Diseases of Mediterranean Forest Systems, Paine T.D. \& Lieutier F. Ed., Springer International Publishing, Switzerland, pp. 211-238.

Branco M., Franco J., Valente C., Mendel Z., 2006 Survey of Eucalyptus gall wasps in Portugal. - Bol. San. Veg. Plagas, 32: 199-202.

Brennan E.B., Gill R.J., Hrusa G.F., Weinbaum S.A., 1999 - First record of Glycaspis brimblecombei (Moore) (Homoptera: Psyllidae) in North America: initial observations and predator associations of a potentially serious new pest of eucalyptus in California. - Pan-Pac. Entomol., 75: 55-57.

Brennan E.B., Hrusa G.F., Weinbaum S.A., Levison JR. W., 2001 - Resistance of Eucalyptus species to Glycaspis brimblecombei (Homoptera: Psyllidae) in the San Francisco Bay area. - Pan-Pac. Entomol., 77: 249-253.

BRUNDU G., 2017 - Le specie di Eucalyptus introdotte in Italia e in Sardegna. - Atti Convegno "Problematiche fitosanitarie dell'eucalipto", Tramatza (OR) 24-25 marzo 2017.

Buffa F., 2015 - Problematiche entomologiche dell'eucalipto in Sardegna e monitoraggio del fitofago di nuova introduzione Psilla lerp (Glycaspis brimblecombei). PhD thesis, Department of Agriculture, University of Sassari, Sassari, Italy, pp. 78.

Burckhardt D., Elgueta M., 2000 - Blastopsylla occidentalis Taylor (Hemiptera: Psyllidae), a new introduced eucalypt pest in Chile. - Rev. Chilena Ent., 26: 57-61.

Burckhardt D., Santana D.L.Q., Terra A.L., Andrade F.M., Penteado S.R.C., Iede E.T., Morey C.S., 1999 Psyllid pests (Hemiptera, Psylloidea) in South American eucalypt plantations. - Mitt. Schweiz. Ent. Ges., 72: 1-10.

Burks R., Mottern J., Waterworth R., Paine, T., 2015 First report of the Eucalyptus gall wasp, Ophelimus maskelli (Hymenoptera: Eulophidae), an invasive pest on Eucalyptus, from the Western Hemisphere. - Zootaxa, 3926: 448-450.

Campbell R.W., 1981 - Population dynamics. In: The Gypsy Moth: Research Toward Integrated Pest Management, Doane C.C. \& McManus M.L. Ed., Technical Bulletin, vol. 1584, U.S. Department of Agriculture, Forest Service,. Washington, MD, USA, pp. 65-214.

Carpintero D.L., Dellapé P.M., 2006 - A new species of Thaumastocoris Kirkaldy from Argentina (Heteroptera: Thaumastocoridae: Thaumastocorinae). - Zootaxa, 1228: 61-68.
Cillo D., Leo P., Sechi D., 2006 - Segnalazioni Faunistiche Italiane. 449. Phoracantha recurva Newman, 1840 (Coleoptera Cerambycidae). - Boll. Soc. Entomol. Ital., 138: 77-78.

Clarke A.R., Paterson S., Pennington P., 1998 Gonipterus scutellatus oviposition on seven naturally cooccurring Eucalyptus species. - Forest Ecol. Manag., 110: 89-99.

Cocco A., Cossu Q.A., Erre P., Nieddu G., Luciano P, 2010 - Spatial analysis of gipsy moth populations in Sardinia using geostatistical and climate models. - Agr. Forest Entomol., 12: 417-426.

Cordero Rivera A., Santolamazza Carbone S., 2000 The effect of three species of Eucalyptus on growth and fecundity of (Gonipterus scutellaris). - Forestry, 73(1): 2129.

Cuello E.M., López S.N., Andorno A.V., Hernández C.M., Botтo E.N., 2018 - Development of Glycaspis brimblecombei Moore (Hemiptera: Aphalaridae) on Eucalyptus camaldulensis Dehnh. and Eucalyptus dunnii Maiden. - Agr Forest Entomol., 20: 73-80.

DaAne K.M., Sime K.R., Dahlsten D.L., Andrews J.W. JR, ZuPARKO R.L., 2005 - The biology of Psyllaephagus bliteus Riek (Hymenoptera: Encyrtidae), a parasitoid of the red gum lerp psyllid (Hemiptera: Psylloidea). - Biol. Control, 32: 228-35.

DaAne K.M., Sime K.R., PAINE T.D., 2012 - Climate and the effectiveness of Psyllaephagus bliteus as a parasitoid of the red gum lerp psyllid. - Biocontrol Sci. Tech., 22: $1305-1320$.

Dahlsten D.L., Daane K.M., Paine T.D., Sime K.R., Lawson A.B., Rowney D.L., Roltschw J., ANDREWs JR. J.W., Kabashima J.N., Shaw D.A., RobB K.L., Downer J.A., Geisel P.M., Chaney W.E., Ingels C.A., VArela L.G., Bianchi M.L., TAYlor G., 2005 - Imported parasitoid helps control red gum lerp psyllid. - Calif. Agric., 59: 229-234.

Deiana V., Pinna C., Buffa F., Mannu R., Satta A., Floris I., 2018 - Population dynamics and seasonal abundance of Thaumastocoris peregrinus in Eucalyptus plantations in Sardinia (Italy). - ReDIA, 101: 101-106. http:// dx.doi.org/10.19263/REDIA-101.18.13

Deidda A., Buffa F., Linaldeddu B.T., Pinna C., Scanu B., Deiana V., Satta A., Franceschini A., Floris I., 2016 - Emerging pests and diseases threaten Eucalyptus camaldulensis plantations in Sardinia, Italy. - iForest Biogeosciences and Forestry, 9: 883-891.

Dhahri S., Ben Jamaa M., Lo Verde G., 2010 - First record of Leptocybe invasa and Ophelimus maskelli eucalyptus gall wasps in Tunisia. - Tunis. J. Plant. Prot., 5: 229-234.

Dittrich-Schröder G., Wingfield M.J., Hurley B.P., SLIPPERS B., 2012 - Diversity in Eucalyptus susceptibility to the gall-forming wasp Leptocybe invasa. - Agr. For. Entomol., 14: 419-427.

Doganlar O., 2005 - Occurrence of Leptocybe invasa Fisher \& La Salle, 2004 (Hymenoptera: Chalcidoidea: Eulophidae) on Eucalyptus camaldulensis in Turkey, with description of the male sex. - Zool. Middle East., 35: 112114.

Dzokou V.J., Tamesse J.L., Burckhardt D., 2009 Jumping plant-lice of the family Psyllidae (Hemiptera: Psylloidea) from west Cameroon: biodiversity and host plants. - Journal of Entomology 6: 1-17.

EPPO, 2005 - Data sheets on quarantine pests. Gonipterus gibberus and Gonipterus scutellatus. - Bull OEPP/EPPO Bull 35:368-370. 
EPPO, 2006 - First report of two new eucalyptus pests in the South of France: Ophelimus maskelli and Leptocybe invasa. - EPPO Rep. Serv. 2006:189.

Ferreira Filho P.J., Wilcken C.F., Lima A.C.V., DE SÁ L.A.N., Do CARMo J.B., Guerreiro J.C., ZanunCio J.C., 2015 - Biological control of Glycaspis brimblecombei (Hemiptera: Aphalaridae) in eucalyptus plantations. Phytoparasitica, 43: 151-157.

Floris I., Buffa F., Deiana V., Pinna C., Satta A., 2016 Nuovi fitofagi dell'eucalipto e impatto sulla produzione mellifera in Sardegna. - Atti XXV Congresso Nazionale Italiano di Entomologia, Padova 20-24 giugno 2016.

Floris I., LuCIANo P., 2017 - Problematiche fitosanitarie dell'eucalipto. - Atti Convegno "Problematiche fitosanitarie dell'eucalipto", Tramatza (OR) 24-25 marzo 2017.

Garcia A., Figueiredo E., Valente C., Monserrat V.J., BRANCO M., 2013 - First record of Thaumastocoris peregrinus in Portugal and of the neotropical predator Hemerobius bolivari in Europe. - Bulletin of Insectology, 66: 251-256.

GILIOMEE, J.H., 2011 - Recent establishment of many alien insects in South Africa - a cause for concern. - African Entomology, 19: 151-155.

Hanks L.M., Millar J.G., Paine T.D., Campbell C.D., 2000 - Classical Biological Control of the Australian Weevil Gonipterus scutellatus (Coleoptera: Curculionidae) in California. - Environ. Entomol., 29: 369-375.

HoDKInson I.D., 1991 - First record of the Australian psyllid Blastopsylla occidentalis Taylor (Homoptera; Psylloidea) on Eucalyptus (Myrtaceae) in Mexico. - PanPac. Entomol., 67: 72.

Hurley B., 2014 - New pest of Eucalyptus detected in South Africa. Available from: http://www.fabinet.up. ac.za/index.php/news-item?id=136.

Ide M.S., Ruiz C.G., Sandoval A.C., Valenzuela J.E., 2011 - Detection of Thaumastocoris peregrinus (Hemiptera: Thaumastocoridae) associated to Eucalyptus spp. in Chile. - Bosque, 32: 309-313.

JACOBS D.H., NESER S., 2005 - Thaumastocoris australicus Kirkaldy (Heteroptera: Thaumastocoridae): a new insect arrival in South Africa, damaging to Eucalyptus trees. South African Journal of Science, 101: 233-236.

Jimenez-Quiroz E., Vanegas-Rico J.M., MoralesMARTíNEZ O., LOMELI-Flores J.R., RODRÍGUEZ-LEYVA E., 2016 - First record of the bronze bug, Thaumastocoris peregrinus Carpintero and Dellapé 2006 (Hemiptera: Thaumastocoridae), in Mexico. - Journal of Agricultural and Urban Entomology 32: 35-39.

Kavallieratos N., Kontodimas D., Anagnou-Veroniki M., Emmanouel N.G., 2006 - First record of the gall inducing insect Ophelimus eucalypti (Gahan) (Hymenoptera: Chalcidoidea: Eulophidae) in Greece. Ann. Benaki Phytopatol. Inst., 20: 125-128.

LAUDONIA S., 2006 - Un nuovo psillide su eucalipto. L'Informatore Agrario, 62(9): 89.

LaUdonia S., Garonna A.P., 2010 - The red gum lerp psyllid, Glycaspis brimblecombei, a new exotic pest of Eucalyptus camaldulensis in Italy. - Bull. Insectol., 63: 233-236.

LAUdOnia S., SASSO R., 2012 - The bronze bug Thaumastocoris peregrinus: a new insect recorded in Italy, damaging to Eucalyptus trees. - Bull. Insectol., 65: 89-93.

Lawson S., Griffiths M., Nahrung H., Noack A., Wingfield C., Slippers B., Lo N., Thu P.Q., LeE S.S.,
LELANA E.N., KeTPHANH S., ZhOU X., EUNGWIJARNPANYA S., 2012 - Biological control of eucalypt pests overseas and in Australia, Final report number FR2012-26. Australian Centre for International Agricultural Research, Camberra, Australia.

LEONARD D.E., 1981 - Bioecology of the Gypsy Moth. In: The Gypsy Moth: Research Toward Integrated Pest Management, Doane C.C. and McManus M.L. Ed., U.S. Department of Agriculture, Washington D.C., pp. 9-29.

Liebhold A.M., Gottschalk K.W., Muzika R.M., Montgomery M.E., Young R., O’DAY K., Kelley B., 1995 - Suitability of North American tree species to the gypsy moth: a summary of field and laboratory tests. U.S. Department of Agriculture Forest Service NE Forest Experimental Station General Technical Bulletin NE-211. U.S. Department of Agriculture, Washington, D.C.

Loch A.D., 2006 - Phenology of Eucalyptus weevil, Gonipterus scutellatus Gyllenhal (Coleoptera: Curculionidae), and chrysomelid beetles in Eucalyptus globulus plantations in south-western Australia. - Agr. For. Entomol., 8: 155-165.

Loch A.D., 2008 - Parasitism of the Eucalyptus weevil, Gonipterus scutellatus Gyllenhal, by the egg parasitoid, Anaphes nitens Girault, in Eucalyptus globulus plantations in southwestern Australia. - Biol. Control, 47: $1-7$.

Loch A.D., Floyd R.B., 2001 - Insect pests of Tasmanian blue gum, Eucalyptus globulus globulus, in south-western Australia: History, current perspectives and future prospects. - Austral Ecol., 26: 458-466.

Loch A.D., MATsuki M., 2010 - Effects of defoliation by Eucalyptus weevil, Gonipterus scutellatus, and chrysomelid beetles on growth of Eucalyptus globulus in southwestern Australia. - For. Ecol. Manag., 260: 13241332.

LonGo S., 2009 - Fitofagi esotici e invasioni biologiche negli ecosistemi forestali. - Atti Accademia Nazionale Italiana di Entomologia, Anno LVII: 69-77.

LuCiano P., Prota R., 1985 - Indagini di base per il controllo di alcuni defogliatori in ambiente forestale. In: Atti del secondo congresso nazionale della società italiana di ecologia, Moroni A., Anelli A. \& O Ravera Ed., Atti 5, Edizioni Zara, Parma, Italy, pp. 823-827.

Mannu R., Buffa F., Pinna C., Deiana V., Satta A., Floris I. - 2018. Preliminary results on the spatio-temporal variability of Glycaspis brimblecombei (Hemiptera Psyllidae) populations from a three-year monitoring program in Sardinia (Italy). - Redia, 101: 107-114. http://dx.doi.org/10.19263/REDIA-101.18.14

ManNu R., Gilioli G., LuCiano P., 2017 - Occupancy of the territory by Lymantria dispar (L.) (Lepidoptera Erebidae) egg masses as a predictive index of damage. Redia, 100: 157-165. http://dx.doi.org/10.19263/REDIA-100.17.14

Mapondera T.S., Burgess T., MATsuKi M., OBerprieler R.G., 2012 - Identification and molecular phylogenetics of the cryptic species of the Gonipterus scutellatus complex (Coleoptera: Curculionidae: Gonipterini). Aust. J. Entomol., 51: 175-188.

MARTíneZ G., BiANCHI M., 2010 - First record in Uruguay of the bronze bug, Thaumastocoris peregrinus Carpintero and Dellapé, 2006 (Heteroptera: Thaumastocoridae). Agrociencia, 14: 15-18.

MARTínez G., Gómez D., TAYLOR G.S., 2014 - First record of the Australian psyllid Blastopsylla occidentalis Taylor (Hemiptera, Psylloidea) from Uruguay. - Trans. R. Soc. S. Aust., 138: 231-236. 
MatsuKi M., KaY N., SERIN J., SCOTT K., 2011 - Variation in the ability of larvae of phytophagous insects to develop on evolutionarily unfamiliar plants: a study with gypsy moth Lymantria dispar and Eucalyptus. - Agr. Forest Entomol., 13: 1-13.

McFadden M.W., McManus M.L., 1991 - An Insect out of control? The potential for spread and establishment of the gypsy moth in new forest areas in the United States. In: Forest Insect Guilds: Patterns of Interaction with Host Trees, Baranchikov Y.N., Mattson W.J., Hain F.P., Payne T.L. Ed., USDA Forest Service General Technical Report NE-153, pp. 172-186.

MENDEL Z., 1985 - Seasonal development of the eucalypt borer, Phoracantha semipunctata, in Israel. Phytoparasitica, 13: 85-93.

Mendel Z., Branco M., Battisti A., 2016 - Invasive SapSucker Insects in the Mediterranean Basin. In: Insects and Diseases of Mediterranean Forest Systems, Paine T.D. \& Lieutier F. Ed., Springer International Publishing, Switzerland, pp. 261-292.

Mendel Z., Protasov A., Fisher N., La Salle J., 2004 Taxonomy and biology of Leptocybe invasa gen. \& sp. $n$. (Hymenoptera: Eulophidae), an invasive gall inducer on Eucalyptus. - Aust. Entomol., 43: 101-113.

Morgan F.D., 1984 - Psylloidea of South Australia. Government of South Australia. Government Printer, South Africa, pp. 136.

Nadel R.L., Slippers B., Scholes M.C., Lawson S.A., NoAck A.E., Wilcken C.F., Bouvet J.P., Wignfield M.J., 2010 - DNA bar-coding reveals source and patterns of Thaumastocoris peregrinus invasions in South Africa and South America. - Biol. Invasions, 12: 1067-1077.

Newete S.W., Oberprieler R.G., Byrne M.J., 2011 - The host range of the Eucalyptus Weevil, Gonipterus "scutellatus" Gyllenhal (Coleoptera: Curculionidae), in South Africa. - Ann. For. Sci., 68: 1005-1013.

NoAck A.E., Coviella C.E., 2006 - Thaumastocoris australicus Kirkaldy (Hemiptera: Thaumastocoridae): First record of this invasive pest of eucalyptus in the Americas. - General and Applied Entomology, 35: 13-14.

NoACK A., Rose H.A., 2007 - Life-history of Thaumastocoris peregrinus and Thaumastocoris $s p$. in the laboratory with some observations on behaviour. - Gen. Appl. Entomol., 36: 27-33.

Paine T.D., Millar J.G., 2003 - Biological control of introduced pests of Eucalyptus in California. Proc. 1st Int. Symp. Biol. Control Arthropods. USDA For. Serv. FHTET-0305, pp. 66-71.

Palmeri V., CAMPolo O., 2006 - Sulla presenza di Phoracantha recurva Newman e Phoracantha semipunctata $F$. (Coleoptera Cerambycidae) in Calabria. - Boll. Zool. Agraria Bachicoltura, 38: 251-254.

Pérez Otero R., Mansilla J.P., Borrajo P., Ruiz F., 2011 - Primera cita en la Península ibérica de Blastopsylla occidentalis Taylor (Homoptera: Psyllidae). - Boletín de Sanidad Vegetal. Plagas, 37: 139-144.

Petro R., Madoffe S.S., Iddi S., 2015 - Infestation density of Eucalyptus gall wasp, Leptocybe invasa Fisher and La Salle (Hymenoptera: Eulophidae) on five commercially grown Eucalyptus species in Tanzania. -Journal of Sustainable Forestry, 33: 276-297.

Piras L., Contini C., Pisano P., 1970 - Sulla introduzione in Europa di un Cerambicide australiano parassita di Eucalyptus: Phoracantha semipunctata Fab. - Boll. Soc. Entomol. Ital., 102: 58-63.

Protasov A., La Salle J., Blumberg D., Brand D., Saphir N., Assael F., Fisher N., Mendel Z., 2007 Biology, revised taxonomy and impact on host plants of Ophelimus maskelli, an invasive gall inducer on Eucalyptus spp. in the Mediterranean area. - Phytoparasitica, 35:50-76.

Pujade-Villar J., Riba-Flinch J., 2004 - Dos especies australianas de eulófidos, muy dañinas para Eucalyptus spp., introducidas en el Nordeste ibérico (Hymenoptera. Eulophidae). - Bol. Soc. Entomol. Aragon., 35: 299-301.

Romano M., 2007 - Nuovi dati sulla presenza in Sicilia di Phoracantha recurva Newman, 1840 (Coleoptera Cerambycidae). - Naturalista Sicil., 31: 241-247.

SANTANA D.L.Q., Burckhardt D., 2007 - Introduced Eucalyptus psyllids in Brazil. - J. For. Res., 12: 337-344.

Soliman E.P., Wilcken C.F., Pereira J.M., Dias T.K.R., Zache B., Dal Pogetto M.H.F.A., BARbosa L.R., 2012 - Biology of Thaumastocoris peregrinus in different eucalyptus species and hybrids. - Phytoparasitica, 40: 223-230.

Sopow S., George S., Ward N., 2012 - Bronze bug, Thaumastocoris peregrinus: a new Eucalyptus pest in New Zealand. - Surveillance, 39: 43-45.

Soufo L., TAmesse J.L., 2015 - Population dynamic of Blastopsylla occidentalis Taylor (Hemiptera: Psyllidae), a psyllis pest of Eucalyptus. - Neotrop. Entomol., 44: 504-512.

Suma P., Nucifora S., Bella S., 2014 - New distribution record of the invasive bronze bug Thaumastocoris peregrinus Carpintero and Dellapé (Heteroptera, Thaumastocoridae) in Italy. - EPPO Bulletin, 44: 179182.

TASSI F., 1969 - Un longicorne australiano per la prima volta in Italia. - Boll. Ass. Romana Entomol., 24: 69-71.

TAYLOR K.L., 1985 - Australian psyllids: a new genus of Ctenarytainini (Homoptera: Psylloidea) on Eucalyptus, with nine species. - Australian Journal of Entomology, 24: 17-30.

Tong Y.G., Ding X.X., Zhang K.C., Yang X., Huang W., 2016 - Effect of the gall wasp Leptocybe invasa on hydraulic architecture in Eucalyptus camaldulensis plants. - Front. Plant Sci., 7: 130. doi: 10.3389/ fpls.2016.00130

ToOKe F.G.C., 1953 - The eucalyptus snout-beetle, Gonipterus scutellatus Gyll. A study of its ecology and control by biological means. - Entomology Memoirs, Department of Agriculture, Union of South Africa 3, pp. 282.

Viggiani G., Nicotina M., 2001 - L'Eulofide galligeno fogliare degli eucalipti Ophelimus eucalypti (Gahan) (Hymenoptera: Eulophidae) in Campania. - Boll. Zool. Agr. Bachic. 33: 79-82.

Wilcken C., Soliman E., De Sá L., Barbosa L.R., Dias T.K.R., Ferreira-Filho P., Rodrigues Oliveira R., 2010 - Bronze bug Thaumastocoris peregrinus Carpintero and Dellapé (Hemiptera: Thaumastocoridae) on Eucalyptus in Brazil and its distribution. - Journal of Plant Protection Research, 50: 201-205. 
72 - Blank Page 